\title{
Dinâmica econômica e empresariamento urbano em cidades médias sob o impacto da reestruturação produtiva
}

Economic dynamics and urban entrepreneurship in medium size cities under the impact of productive restructuring

\begin{abstract}
The article comparatively analyzes contemporary urban development processes of medium-sized cities taking into account the restructuring process in the context of economic liberalization occurred from the 1990s to 2011. The empirical basis consisted of three medium-sized cities in the state of São Paulo: Piracicaba, Bauru and Rio Claro. The data on economic development and public spending showed the predominance of business interests in the management of these cities with the purpose of making them attractive for private investment occasioning urban entrepreneurship. On the one hand, this scenario is connected to the emptying of the state and its urban and regional development policies and on the other hand, there is the new leading role of municipalities in the effort to readjust their productive structures to attract private enterprises.
\end{abstract}

\section{Keywords}

economic liberalization; restructuring of production; urban entrepreneurship; medium-sized cities.

JEL Codes R58; R11.
Eliana T. Terci

Universidade de São Paulo

Jefferson O. Goulart

Universidade Estadual Paulista

Estevam V. Otero

Universidade Metodista de Piracicaba

\section{Resumo}

$O$ artigo analisa comparativamente processos contemporâneos de desenvolvimento urbano de cidades médias, tendo em conta o processo de reestruturação produtiva no contexto da liberalização econômica a partir da década de 1990 até 2011. A base empírica consistiu de três cidades médias do interior paulista: Piracicaba, Bauru e Rio Claro. Os dados sobre o desenvolvimento econômico e o gasto público evidenciam o predominio de interesses empresariais na gestão dessas cidades com a finalidade de torná-las atrativas para as inversões privadas, ensejando o empresariamento das cidades. A ação do poder público local se revelou determinante para a dinamização da economia urbana e regional. Esse cenário está ligado, de um lado, ao esvaziamento do Estado $e$ de suas políticas de desenvolvimento urbano e regional e, de outro, ao novo papel destacado dos municípios no esforço de readequação de suas estruturas produtivas visando a atrair os empreendimentos privados.

\section{Palavras-chave}

liberalização econômica; reestruturação produtiva; empresariamento urbano; cidades médias.

Códigos JEL $R 58 ; R 11$. 


\section{Introdução}

Este texto aborda, em perspectiva comparada, a dimensão econômica dos processos contemporâneos de desenvolvimento urbano de três cidades médias do interior do estado de São Paulo (Piracicaba, Bauru e Rio Claro), no contexto da reestruturação produtiva e da liberalização a partir da década de 1990 até 2011.

A escolha desses três municípios se justifica por serem cidades de porte médio, conforme os critérios do IBGE, com "população urbana entre 100 mil e 500 mil habitantes" (Braga, 2005, p. 2245), bem como pelas "funções e, principalmente, o papel que desempenham na rede urbana regional, nacional e internacional" (Castello Branco, 2006, p. 246). São municípios que polarizam as microrregiões das quais são sede e que comportam variáveis comparáveis: de um lado, pelas escalas demográficas e pelos perfis locacionais e espaciais relativamente similares e, de outro, em virtude das especificidades de suas formações socioeconômicas que marcam sua singularidade. Piracicaba se distingue pelo polo metalomecânico que ainda a projeta. Bauru e Rio Claro, outrora importantes entroncamentos ferroviários, tiveram diferentes evoluções após o desmonte deste modal de transporte: Bauru se consolidou como polo regional e centro de prestação de serviços, enquanto Rio Claro voltou-se para o setor industrial.

No plano teórico-metodológico, o trabalho compreendeu levantamento, classificação e análise de dados secundários sobre as dinâmicas do desenvolvimento urbano e regional e das finanças públicas das cidades selecionadas a partir de diversas fontes (IPEADATA, IBGE, SEADE, Prefeituras Municipais), além de revisão da literatura sobre a interiorização do desenvolvimento, a reestruturação produtiva e os impactos do movimento de liberalização. Assim, adotou-se a hipótese de que, em um contexto de mudança da dinâmica econômica com progressiva liberalização a partir do colapso do padrão desenvolvimentista e de esvaziamento da liderança do Estado e de suas agências e políticas de desenvolvimento urbano e regional, os municípios e governos locais assumiram o desafio de readequar suas estruturas produtivas visando a atrair os empreendimentos privados, adotando o modelo do empresariamento urbano.

O texto está estruturado sequencialmente da seguinte forma: análise dos termos em que transcorreram tais mudanças da economia nacional, as políticas de liberalização econômica e a mudança de papel das cida- 
des; a interiorização do desenvolvimento e o papel das cidades médias; a emergência do empresariamento urbano e sua influência no contexto da reestruturação produtiva; a apreciação comparada das finanças públicas das cidades selecionadas; e, finalmente, são esboçadas algumas hipóteses conclusivas com base nessa sequência analítica.

\section{Dinâmica econômica, liberalização e mudança do papel das cidades}

A dinâmica econômica do desenvolvimento regional e urbano das últimas décadas esteve condicionada por quatro ordens de influências: (i) pela derrocada do desenvolvimentismo que caracterizou a condução da política econômica desde os anos 1930 sob os auspícios do Estado nacional; (ii) pela inserção internacional brasileira a partir dos anos 1990, que promoveu abertura comercial e financeira, privatização, desregulamentação dos mercados e intenso processo de reestruturação produtiva; (iii) pela política de estabilização da moeda apoiada no manejo da taxa de juros e na âncora cambial (Plano Real); e (iv) pelas tentativas recentes de retomada do crescimento econômico através de políticas públicas sociais e setoriais.

A reversão do ciclo virtuoso de crescimento que caracterizou o desenvolvimentismo brasileiro desde o pós-guerra teve desfecho dramático no final da década de 1970, com profunda crise fiscal, endividamento externo e inflação, movimento que fragilizou o Estado e permitiu o avanço do neoliberalismo e a abertura econômica dos anos 1990, expressando a política de adesão subordinada aos ditames do Consenso de Washington. ${ }^{1}$ Seguiu-se profundo desmonte do aparato estatal com a privatização de empresas e desativação de programas estratégicos, além da submissão da política macroeconômica a uma sequência de planos fracassados de combate à inflação. Ainda que o Plano Real (1994) tenha sido exceção, seu êxito foi alcançado com grande sacrifício para o crescimento da economia e do emprego, em virtude dos juros elevados e do câmbio sobrevalorizado (Carneiro, 2002).

A indústria de transformação foi extremamente penalizada, registrando perda acentuada de participação no Produto Interno Bruto (PIB), indican-

1 Conjunto de 10 medidas liberalizantes de ajuste proposto no âmbito do Fundo Monetário Internacional e do Banco Mundial para os países em desenvolvimento, principalmente com vistas à sua inserção no mercado globalizado e acesso aos fluxos financeiros (Fiori, 1995). 
do preocupante processo de desindustrialização ${ }^{2}$ no país desde meados da década de 1980: após a participação recorde de $27,2 \%$ no PIB, perdeu sistematicamente seu peso relativo, tendo se mantido num patamar entre 15\% e 16\% entre 1997 e 2010 (DIEESE, 2011).

A mudança de orientação política, a melhora da conjuntura internacional e a implantação das políticas sociais e setoriais a partir de 2003, ainda que tivessem efeito positivo sobre o crescimento do nível de emprego e dos salários, não contribuíram para o crescimento da indústria de transformação. Para o período 1996-2008, "em apenas três anos a taxa de crescimento da indústria superou a da economia, a saber: 2000, 2003 e 2004", e assim "o PIB cresceu à frente do valor adicionado da indústria de transformação, revelando continuidade da perda de dinamismo da indústria no período posterior a 1995" (Oreiro; Feijó, 2010, p. 228).

O maior entrave à retomada desenvolvimentista tem sido o descompasso entre as estratégias de crescimento e a política macroeconômica sustentada nas taxas de juros elevadas, o que paradoxalmente alimenta a entrada de capital estrangeiro, mas inibe o investimento produtivo (Suzigan; Furtado, 2006; Cano, 2012). A derrocada do desenvolvimentismo, não por acaso, coincide com a crise de acumulação das economias avançadas que, desde meados dos anos 1970, tem implicado em severa reestruturação produtiva, visando a elevar a produtividade, reduzir custos e ampliar mercados. Castro (2001) esquematizou os principais traços desse processo em escala nacional: 1) adoção de métodos modernos de gestão para atender padrões internacionais de eficiência; 2) modernização/diversificação da linha de produtos ajustando a oferta às novas exigências do mercado doméstico; e 3) deslocamento de fábricas para regiões com economias de aglomeração (infraestrutura, mão de obra e matérias-primas baratas, incentivos fiscais, qualidade de vida) superiores às proporcionadas pelas regiões metropolitanas.

Nesse cenário, a retórica neoliberal tem valorizado os gestores locais, alçados à condição de líderes de cidades, cuja competência é medida pela capacidade de criar ambiente favorável à competição das empresas e po-

2 A desindustrialização é identificada como a tendência de queda da participação da indústria de transformação no PIB. É distinta da tendência secular de terceirização das economias no longo prazo em virtude dos diferenciais de elasticidade-renda da demanda que ocorre nos países desenvolvidos, daquela que ocorre nos países em desenvolvimento, como no Brasil, em que a estrutura produtiva não atingiu ainda níveis competitivos de produtividade. Nestes casos, a desindustrialização é prematura (Oreiro; Feijó, 2010; Cano, 2012). 
sicionar a cidade na disputa pela localização dos negócios. Dessa forma, as cidades são projetadas como a "escala geográfica de maior relevância no capitalismo globalizado", conectando-se diretamente com os fluxos de negócios, esvaziando as funções da esfera federal (Fernandes, 2001).

Assim, as cidades estariam adquirindo forte protagonismo, tornando-se atores políticos destacados ao realizar a articulação entre as administrações públicas, a sociedade civil e as diferentes instâncias do Estado na promoção de acordos e associações visando à dinamização das suas potencialidades e à "promoção do bem-estar de sua população" (Castells; Borja, 1996). Autores como esses sustentam sua argumentação nas inúmeras iniciativas dos atores urbanos que, mediante a recessão econômica dos anos 1970, militaram pelo protagonismo das cidades, seja realizando colóquios internacionais como a Conferência de Cidades Europeias, que criou o movimento das Eurocidades (1989), seja na experiência das cidades asiáticas que se projetam autonomamente, divulgando perfis e estatísticas econômicas, numa demonstração de "forte complementaridade entre o governo da cidade e o conjunto dos agentes econômicos, todos orientados para os mercados externos" (Idem, p. 153). Na América Latina - onde abundam problemas estruturais herdados de um processo de desenvolvimento concentrador e excludente ${ }^{3}$, os quais se traduzem em problemas urbanos como déficit habitacional, deterioração dos equipamentos e bens públicos, degradação ambiental, insegurança pública, congestionamentos etc. -, as respostas têm se limitado à proposição de emancipação das cidades. Sendo assim, a retomada do crescimento econômico, a democratização e a ascensão da participação política possibilitariam a reação à crise pela aprovação de grandes projetos de reforma urbana protagonizados pelas lideranças locais (Idem).

Analisando a experiência brasileira, Fernandes (2001) questiona esse suposto poder de decisão da esfera local na ordem globalizada, atentando para o fato de que a ausência do papel regulador do Estado nessa inserção direta submeteu a gestão urbana aos interesses hegemônicos das corporações com poder de investimento. Impulso econômico e desemprego empurraram as cidades numa competição desenfreada pelas decisões loca-

3 Referimo-nos aos processos de substituição de importações que caracterizaram o desenvolvimento das economias latino-americanas que, ao priorizarem a industrialização sob regimes autoritários, ignoraram os passivos estruturais (concentração fundiária, concentração regional e de renda) e as reformas que se faziam urgentes para revertê-los. 
cionais dos negócios, por meio da oferta de benefícios e subsídios, muitas vezes além de suas reais possibilidades. Nesses termos

são as estratégias empresariais globais, liberadas de limites e regulações nacionais e supranacionais as que mais impacto causam sobre a vida das populações urbanas; e a visão da renovada importância das cidades nesta ordem global é, também ela, uma reação à preponderância daquelas. (Fernandes, 2001, p. 26).

Esse alerta leva a relacionar essa singular descentralização das esferas de poder - herdada da Constituição de 1988, que alçou as cidades à condição de entes federados autônomos - à dinâmica mais geral de desenvolvimento do capitalismo em sua fase contemporânea e à inflexão dos anos 1970. Lipietz (1996) ajuda a entender esse processo: o declínio flagrante do investimento industrial e consequente aumento do desemprego, aliado à crise fiscal e à fragilização dos Estados nacionais em seu papel planejador do desenvolvimento econômico, desarticulou o regime fordista-taylorista de desenvolvimento assentado na relação capital-trabalho que combinava princípios de gestão administrativa com estímulos salariais e um sofisticado arcabouço social de proteção ao trabalho. $O$ crescimento da produtividade desacelerou-se, implicando queda crescente da lucratividade num momento de internacionalização dos mercados e, ao mesmo tempo em que expunha as profundas diferenças nacionais em termos dos compromissos trabalhistas, possibilitava ao setor produtivo deslocar suas plantas ou parte delas para países com melhores vantagens: "nos dois casos (lucratividade e competitividade), a rigidez dos contratos salariais era questionada, o fordismo estava condenado" (Lipietz, 1996, p. 12). A saída para alguns países, como Alemanha e Itália, foi o estabelecimento de um novo compromisso com base nos recursos humanos, enquanto para outros, como EUA, Reino Unido, França e sul da Europa, a opção foi a flexibilização, "uma 'brasileirização' que resultou no neotaylorismo" (Idem).

No Brasil, a adoção do padrão liberal-flexível de acumulação - combinada à crise do padrão keynesiano de gestão pública e ao avanço agressivo do neoliberalismo - induziu à guerra fiscal, que, revigorada, serviu como instrumento de competição entre as cidades e atração dos investimentos, principalmente das corporações transnacionais, promovendo-se um "verdadeiro leilão de localização" (Cano et al., 2007). Assim, "as antigas ideias de planejamento e desenvolvimento foram substituídas pelas políticas dos APLs (Arranjos Produtivos Locais), nome inventado no Brasil para substituir, com fragilidade, os clusters ou verdadeiros distritos industriais" (Cano 
et al., 2007, p. 38). Ou seja, o urbano adquire nova dimensão no processo de acumulação capitalista: "reproduzir não mais as condições necessárias para a acumulação capitalista no espaço urbano, mas reproduzir diretamente o capital por meio da produção do espaço urbano" (Carlos et al., 2015, p. 8).

Essa, porém, não foi a primeira distorção no processo brasileiro, pois a industrialização também foi acompanhada de um arcabouço social inacabado - o "fordismo periférico", conforme Lipietz (1996) -, que combinou salários baixos e mercado de trabalho desintegrado e se traduziu numa urbanização acelerada dando origem a megacidades com toda sorte de problemas como favelização, periferização, precarização da infraestrutura urbana com nítida hierarquia social, deterioração dos serviços públicos, ineficiência dos sistemas de transportes coletivos etc.

Lipietz (1996) assegura que os países que buscaram a "mobilização negociada e a qualificação dos seus recursos humanos" obtiveram resultado mais positivo, ou seja, "a divisão social do espaço tornou-se muito menos intensa nas redes de distritos do pós-fordismo 'mobilizado' do que nos megapolos aleatórios do pós-fordismo 'flexível'” (Lipietz, 1996, p. 14).

Essas interpretações traduzem o que Harvey denominou empresariamento urbano, orientação para a gestão urbana no enfrentamento da crise do modelo fordista-keynesiano da fase áurea do capitalismo. ${ }^{4}$ Compreendendo a cidade simultaneamente como "produto e condição de processos sociais de transformação vigentes na fase mais recente do desenvolvimento capitalista" (Harvey, 1996, p. 48), inevitavelmente a derrocada do padrão

$4 \bigcirc$ termo aparece pela primeira vez com a tradução empresariamento em artigo de David Harvey, publicado na revista Espaço \& Debates, em 1996, numa tradução de Luís Octávio da Silva e Micaela Krumhoz, com o título "Do gerenciamento ao empresariamento urbano: a transformação da administração urbana no capitalismo tardio". Em 2005, uma publicação da Editora Annablume, com o título "A Produção Capitalista do Espaço", reunindo artigos de D. Harvey com tradução de Carlos Szlak, reedita o mesmo artigo, mas emprega o termo empreendedorismo urbano em lugar de empresariamento. Oliveira (2015) oferece uma explicação persuasiva sobre a diferença: para esta autora, ainda que o termo original em inglês entrepreneurialism possa ter as duas traduções, a distinção se faz necessária porque a análise atenta do texto de Harvey revela que o emprego do termo alude ao conceito de empreendedorismo desenvolvido por Schumpeter (1997) para descrever a ação inovadora do empreendedor capitalista que tira a economia de seu estado estático (fluxo circular) e promove o desenvolvimento, não se limitando à transposição de práticas empresariais na gestão urbana. Nas palavras da autora: "o que define o empreendedorismo urbano é o uso do lugar com fins especulativos, por coalisões com interesse no crescimento econômico" (Oliveira, 2015, p. 14). Não obstante a pertinência desses argumentos e considerando que não são expressões necessariamente antitéticas, optamos pela manutenção da tradução original empresariamento, seja por coerência em relação às análises anteriores, seja porque tal escolha não obscurece nem se contrapõe aos fundamentos que distinguem o conceito. 
de acumulação atribuiria novo papel às cidades e à urbanização, conferindo à gestão conduta proativa. A exemplo da Conferência de Cidades Europeias mencionada por Castells e Borja (1996), sob uma perspectiva analítica oposta a estes espanhóis, Harvey destaca um evento que lhe parece ter sido fundante desta nova orientação: um colóquio realizado na cidade francesa de Orléans, em 1985, reunindo acadêmicos, empresários e políticos de oito grandes cidades de sete países centrais, cuja tarefa era encontrar formas de enfrentamento da crise fiscal:

O colóquio apontou para um forte consenso: os governos urbanos tinham que ser muito mais inovadores e empreendedores, abertos para explorar diferentes meios de aliviar as suas condições miseráveis e assim assegurar um futuro melhor para suas populações. O único ponto de discordância referia-se à melhor forma de fazê-lo. Deveriam os governos urbanos sustentar ou mesmo ter um papel direto na criação de novas empresas e, se tal, de que tipo? Ou deveriam lutar para preservar ou mesmo assumir fontes de emprego ameaçadas e, se tal, quais? Ou deveriam ainda, simplesmente, se ater à provisão de infraestrutura, de projetos de caráter local, incentivos fiscais e atrações culturais e sociais que remodelariam antigas formas de atividades econômicas e atrairiam novas? (Harvey, 2005, p. 166).

Seguindo esse modelo, cabe na sequência, identificar os empresários/empreendedores e suas pretensões. As evidências empíricas permitem inferir que tal prática demanda uma coalizão de forças políticas, geralmente a partir de ativistas engajados nas associações comerciais, industriais, educacionais, cenário em que o governo assume função executiva e coordenadora. Tal iniciativa depende de atores com capacidade de liderança para viabilizar a coalizão, seja "um prefeito carismático, um administrador urbano sagaz ou um abastado líder empresarial" (Harvey, 2005, p. 172). Decorrem três características distintivas do empresariamento que podem ser generalizadas: i) estabelecimento de parcerias público-privadas para a viabilização de projetos "inovadores" que justificam a concessão de terra urbana para empreendimentos imobiliários particulares; ii) caráter especulativo dos projetos que resulta da natureza de parceria público-privada, em que o risco em geral tem sido assumido pelo poder público e iii) foco do empresariamento na economia local e em projetos pontuais, em detrimento da promoção de melhorias que digam respeito à cidade como um todo. Ou seja, "o mercado produz a cidade, não planeja a cidade" (Oliveira, 2015, p. 15).

Considerando o cenário competitivo que esta nova orientação invoca para a gestão urbana, principalmente numa conjuntura de retração da atividade econômica, de parcos investimentos e de avanço do neoliberalismo com a retração da esfera nacional, o empresariamento urbano explora os "dife- 
renciais" de suas localidades na atração dos negócios, ou mesmo os produz, revitalizando áreas ou criando outras. Tais ações contribuem para a fragmentação do espaço, do mercado de trabalho e da própria sociedade, rompe laços de solidariedade historicamente construídos que garantiam direitos sociais e "lança a localidade num sistema globalizado de acumulação sobre o qual exerce comando absolutamente inexpressivo" (Fernandes, 2001, p. 34).

Essas ocorrências têm implicações profundas na visão de Harvey, pois além de ressignificarem a urbanização, atribuindo-lhe papel ativo no desenvolvimento político-econômico, reifica a cidade, que, de objeto, passa a sujeito das transformações, radicalizando seu status mercadológico. Ainda que se considere tal dinâmica como condição capitalista por excelência, o que torna os conceitos relativamente instáveis, o que se transformou fundamentalmente foi o urbano (entendido como configuração de práticas espaciais interligadas de atores sociais de diferentes classes), que passou a prescindir da determinação de um espaço físico rígido, haja vista os extremos que se manifestam na fragmentação cada vez maior dos espaços com bairros, distritos e comunidades que se tornam átomos da cidade, e a ligação virtual casa-trabalho que "tornam absurdo certo conceito de cidade enquanto unidade física hermeticamente murada ou mesmo domínio administrativo coerentemente organizado (...). No entanto, persiste o fundamento espacial de alguma forma, com significados e efeitos específicos" (Harvey, 1996, p.171).

Ainda que se refira prioritariamente às regiões metropolitanas, é notável que, nesse cenário especulativo e móvel, as gestões públicas em maior ou menor grau são compelidas ao empresariamento urbano, fazendo vistas grossas aos velhos e persistentes problemas, sobretudo os relativos à segregação urbana. Ou seja,

se durante largo periodo o debate acerca da questão urbana remetia, entre outros, a temas como crescimento desordenado, reprodução da força de trabalho, equipamentos de consumo coletivo, movimentos sociais urbanos, racionalização do uso do solo, a nova questão urbana teria, agora, como nexo central a problemática da competitividade urbana. (Vainer, 2000, p. 76).

A cidade torna-se uma mercadoria a ser vendida, e o marketing urbano, a principal ferramenta do planejamento, de modo que os prefeitos "mais parecem vendedores ambulantes que dirigentes políticos", pois "o mercado externo e, muito particularmente, o mercado constituído pela demanda de localizações pelo grande capital é o que qualifica a cidade como mercadoria" (Idem, p. 80). 
A literatura chama atenção para as consequências dramáticas desse processo que substitui o planejamento e estimula a competição urbana. O empresariamento urbano é ele mesmo um forte estimulador da volatilidade dos investimentos e da localização dos empreendimentos ao criar toda sorte de facilidades às instalações das empresas. ${ }^{5}$ Do ponto de vista distributivo, é óbvia a concessão de subsídios públicos ao setor privado em nome da geração (questionável) de empregos e renda e de tributos para os cofres públicos. Em contrapartida, isto significa a redução de recursos para programas mais abrangentes. Finalmente, vale considerar as consequências perversas decorrentes do processo de "destruição criadora" que o empresariamento urbano enseja: as inovações implantadas para promoção do investimento e do consumo, além da valorização das propriedades, contribuem para a especulação imobiliária e para a reprodução da segregação urbana (revitalização e/ou criação de áreas nobres por meio de projetos de gentrification, periferização das camadas sociais mais empobrecidas, etc.).

Harvey (2005) oferece uma perspectiva mais promissora, entretanto, ao considerar esse fenômeno de um ponto de vista crítico: o reconhecimento dos contrastes criados por essa orientação e o direcionamento para uma gestão pautada pela ideia da cidade como corporação coletiva em que a tomada de decisão se faz de forma democrática, ou seja, "o problema é arquitetar uma estratégia geopolítica de união interurbana que mitigue a concorrência interurbana, e mude os horizontes políticos da localidade, criando um desafio mais generalizável em relação ao desenvolvimento capitalista desigual" (Idem, p. 189). ${ }^{6}$ Nas próximas seções, o conceito será analisado em sua dimensão empírica.

5 Harvey $(1996,2005)$ chama a atenção para a efemeridade das vantagens adquiridas pelas cidades: uma vez que a competição entre elas se faz por meio de investimentos destinados a torná-las atraentes como centros de consumo, nada impede que outros lugares rapidamente sejam imitados, tornando a vantagem inicial passageira.

6 Para a interpretação de um estudo de caso orientado para a inclusão social e urbana, ver a experiência de Santo André (Feldman; Leme, 2001). Iniciativas dessa natureza - voltadas ao fortalecimento dos pequenos empreendimentos e cooperativas de trabalhadores de maneira a torná-los menos dependentes do grande capital - são dignas de registro. Neste caso, segundo o então prefeito Celso Daniel (PT), a condição viabilizadora teria sido a existência de uma "comunidade cívica", constituída pela presença de uma classe operária forte, organizada e de tradição oposicionista. Não obstante, o alcance desse estilo de comunidade cívica é limitado, pois não incorpora os pequenos empreendimentos dependentes do grande capital, os quais preferem se manter isolados, nem a grande massa trabalhadora, potenciais empreendedores que se mantêm alheios a essa cultura. 


\section{Interiorização do desenvolvimento e o papel das cidades médias}

A distribuição territorial brasileira se formou e se reproduziu projetando as diversas regiões a partir de determinantes exógenos, a saber, o comércio internacional com as nações europeias e norte-americana. $\bigcirc$ processo de industrialização, fortemente concentrado no centro-sul do país, não eliminou a dependência externa e acentuou as clivagens regionais. Resultou em dramática concentração econômica e demográfica, dando origem à Região Metropolitana de São Paulo (RMSP), principal polo de atração de população migrante: em 1960, com população de aproximadamente 5 milhões de habitantes, 36,7\% da população do estado de São Paulo.

O ponto de inflexão localiza-se nos anos $1970 \mathrm{com}$ as políticas de desconcentração regional do II Plano Nacional de Desenvolvimento (PND) e resulta em queda da participação da RMSP na indústria a $26 \%$ do PIB em 1990. Para São Paulo, o principal desdobramento da desconcentração produtiva foi o espraiamento da indústria para seu interior, facilitado por "uma rede de centros urbanos de tamanho médio, por certa tradição industrial e pela existência de uma rede estadual de centros de pesquisa e ensino distribuídos por várias cidades" (Diniz, 1993, p. 50). Esse diagnóstico é compartilhado pelo Programa Cidades Médias, o qual sintetizava a disposição do governo paulista de torná-las receptoras de investimentos industriais (Souza, 2004). O governo paulista galvanizou os efeitos dinâmicos da desconcentração industrial, convertendo-a em importante processo de interiorização: entre 1970 e 2003, enquanto a participação da RMSP na indústria brasileira declinou sua participação de $43,5 \%$ para $17 \%$, o interior paulista seguiu aumentando seu peso relativo, subindo de $14,7 \%$ para $27 \%$ no mesmo período.

O colapso do projeto desenvolvimentista, que implicou no abandono das políticas de desconcentração urbano-regionais do II PND, porém, não resultou na reconcentração industrial nas metrópoles. A explicação desse fenômeno merece análise mais aprofundada, mas o conceito de cidade global de Sassen (1998) oferece elementos elucidativos: sua emergência decorre do processo da mundialização do capital, da dominância das atividades financeiras e de serviços sobre as atividades produtivas propriamente ditas e ressignificam o papel das metrópoles, as quais recuperam a força aglomerativa ao assumirem funções mais elevadas nas escalas de localização 
dos negócios, atraindo empresas dedicadas a atividades inovadoras e de ponta, "parece[m] beneficiar-se do fato de estarem localizadas na região central dos grandes centros do comércio internacional, por mais elevados que sejam seus custos" (Sassen, 1998, p. 90). As cidades localizadas fora das áreas metropolitanas se tornam destinos das empresas que desempenham funções mais prosaicas e pautam suas escolhas pelas localidades que lhes garantam vantagens de custos produtivos.

No Brasil, esse movimento foi incrementado pelo processo de reestruturação industrial dos anos 1990, cujo paradigma também seguiu o padrão internacional. O Programa de Reestruturação e Racionalização Empresarial submeteu a indústria ao mandamento "mudar para ficar" e, como decorrência, alterou a geografia dos negócios no país.?

No período contemporâneo, "seja por meio de uma produção própria, seja, sobretudo, funcionando como redistribuidora, a cidade média representa um ponto de difusão da produção e dos valores do sistema socioeconômico de que faz parte" (Amorim; Serra, 2001, p. 19; 21). Assim, a reestruturação produtiva impactou as cidades do interior paulista cujas externalidades positivas foram largamente ampliadas para atender às metas empresariais de competitividade, tais como infraestrutura urbana de qualidade, mão de obra qualificada e barata e subsídios fiscais. Trataremos a seguir de como o processo de reestruturação produtiva - caracterizado pela relocalização dos negócios e pelo padrão de urbanização dele derivado - impactou as cidades médias.

\section{Evolução econômica sob o impacto da reestrutura- ção produtiva e do empreendedorismo urbano}

Piracicaba, Bauru e Rio Claro são importantes cidades médias do interior paulista. Com 368.016 habitantes e taxa de urbanização de 98,04\% (2014), Piracicaba ocupa $8^{a}$ posição no ranking municipal de emprego industrial paulista em 2013. Bauru caracteriza-se por uma economia de serviços, conta 352.654 habitantes e taxa de urbanização de 98,3\% (2014), ocupan-

7 Dois casos são exemplares: o setor automobilístico, que se desconcentrou da região do $\mathrm{ABC}$ e migrou suas unidades para diversas áreas do estado e do país, e o dos setores de calçados e têxteis, que se deslocaram para a região Nordeste. O ranking do PIB Municipal realizado pelo SEADE em 2012 é elucidativo deste processo (SEADE, 2012). 
do $13^{\mathrm{a}}$ posição no ranking paulista no setor serviços. Rio Claro distingue-se pelo perfil industrial: com população de 187.994 habitantes e taxa de urbanização de $97,68 \%$, figura na $19^{a}$ posição no ranking paulista de empregos industriais (2013). ${ }^{8}$

O quadro de referência da rede urbana brasileira (REGIC) permite dimensionar o papel dessas cidades: Piracicaba e Rio Claro fazem parte da mesma aglomeração, sendo que Rio Claro (Centro Sub Regional A) está subordinado à rede de influência de Piracicaba (Capital Regional C). ${ }^{9}$ Ambas as cidades estão subordinadas a Campinas (Capital Regional A), que se interpõe entre elas e a capital paulista (IBGE, 2008).

Bauru, também classificada como Capital Regional C em virtude de sua localização, faz o elo entre a centralidade que representa na região centro-oeste do estado e a capital. Essa distância de São Paulo ajuda a explicar sua condição de polo regional e o peso relativo do setor de serviços, cuja participação na composição do Valor Adicionado (VA) do município atingiu $81,92 \%$ em 2012 , contra $17,82 \%$ da indústria e apenas $0,26 \%$ da agropecuária (Seade, 2014).

\section{Gráfico 1 Piracicaba, Bauru e Rio Claro: evolução do PIB (valor adicionado) municipal}

\section{0 a 2010 (em reais de 2000)}

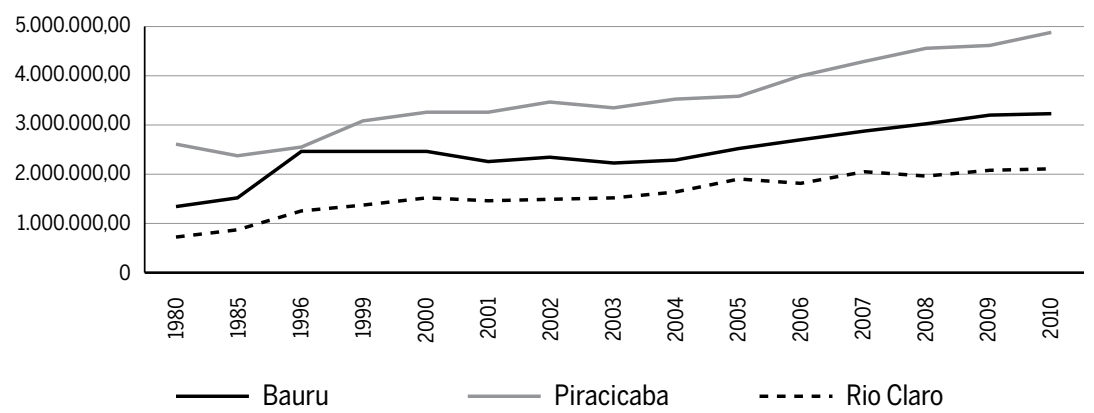

Fonte: IPEADATA. Elaboração própria.

8 Os dados demográficos são provenientes da base disponibilizada pelo SEADE, e as informações sobre emprego foram extraídas do Ranking de empregabilidade realizado pela Fiesp. 9 A hierarquia levou em consideração a classificação dos centros de gestão do território, a dimensão regional, a intensidade de relacionamentos e a diferenciação regional. Tem-se assim, resumidamente, cinco níveis de gestão territorial, a saber: Metrópole, Capital Regional (subdividida em três categorias A, B e C), Centro Sub Regional (subdivididos em duas categorias A e B), Centro de Zona (subdivididos em duas categorias A e B) e Centro Local (cidades menores) (IBGE, 2008). 
Ainda que venha sofrendo perda com o processo de desindustrialização, em Piracicaba a indústria representou $32,73 \%$ do VA, os serviços $65,54 \%$ e a agricultura $1,73 \%$; já em Rio Claro o peso da indústria é ligeiramente superior: 40,16\%; os serviços, 58,92\%; e agropecuária, 0,92\%. O gráfico 1 apresenta a evolução do PIB (Valor Adicionado) desses municípios e revela o comportamento diferenciado dessas economias desde 1980.

A análise da evolução das taxas de crescimento da indústria comparativamente ao VA desses municípios permite observar os efeitos das políticas macroeconômicas sobre o seu desempenho. ${ }^{10} \mathrm{O}$ fenômeno da desindustrialização que acometeu a economia brasileira desde 1985 afetou todas as cidades, principalmente Piracicaba e Rio Claro. A seguir examinamos cada cidade individualmente.

\section{Piracicaba}

Para o período 1980-1996, observa-se o comportamento diferenciado de Piracicaba: o VA declinou expressando as quedas setoriais da indústria e serviços, porém, entre 1980 e 1985, essa queda foi maior que da indústria, que atingiu o maior peso relativo na composição do produto $(62,84 \%)$. Entre 1985 e 1999, enquanto o setor serviços se recuperou elevando o VA, a indústria seguiu caindo. Piracicaba, antes beneficiária do Programa Nacional do Álcool (Proálcool) e da interiorização da indústria paulista no âmbito das políticas do II PND, sofreu os efeitos da crise e da desativação desse programa no governo Collor. No intervalo 1985-1996, a coincidência entre a reversão cíclica dos investimentos do Proálcool e a reestruturação industrial impôs profundo ajuste do complexo canavieiro piracicabano, representado pela agroindústria sucroalcooleira e pela indústria metalomecânica, implicando na perda de participação da indústria no VA municipal, que atinge $44,42 \%$ (Terci, 2009).

10 Conforme a metodologia das estimativas do Produto Interno Bruto dos municípios brasileiros nos anos censitários de 1970, 1975, 1980, 1985 e 1996 que se encontram na página regional do Ipeadata. Adotou-se o procedimento sugerido por Oreiro e Feijó (2010), comparando as taxas de crescimento ao invés da composição do PIB. Essa opção foi escolhida em virtude das dificuldades surgidas para a comparação da composição setorial do PIB entre os períodos anterior e posterior a 1995 em razão da mudança de metodologia de cálculo do PIB adotada pelo IBGE em 2007. 
A partir de 2002 a indústria piracicabana se recupera acompanhando o crescimento do VA da indústria de transformação brasileira (2004-2008), mantendo participação em torno de $40 \%$. O tradicional complexo metalomecânico - o maior do país relacionado à agroindústria sucroalcooleira (metalúrgica básica, máquinas e equipamentos, produtos de metal) - ganhou alento com o aquecimento do programa do combustível alternativo, a difusão do motor flex e a expansão dos mercados nacional e internacional.

\section{Gráfico 2 Piracicaba - evolução total e setorial do Valor Adicionado (reais de 2000)}

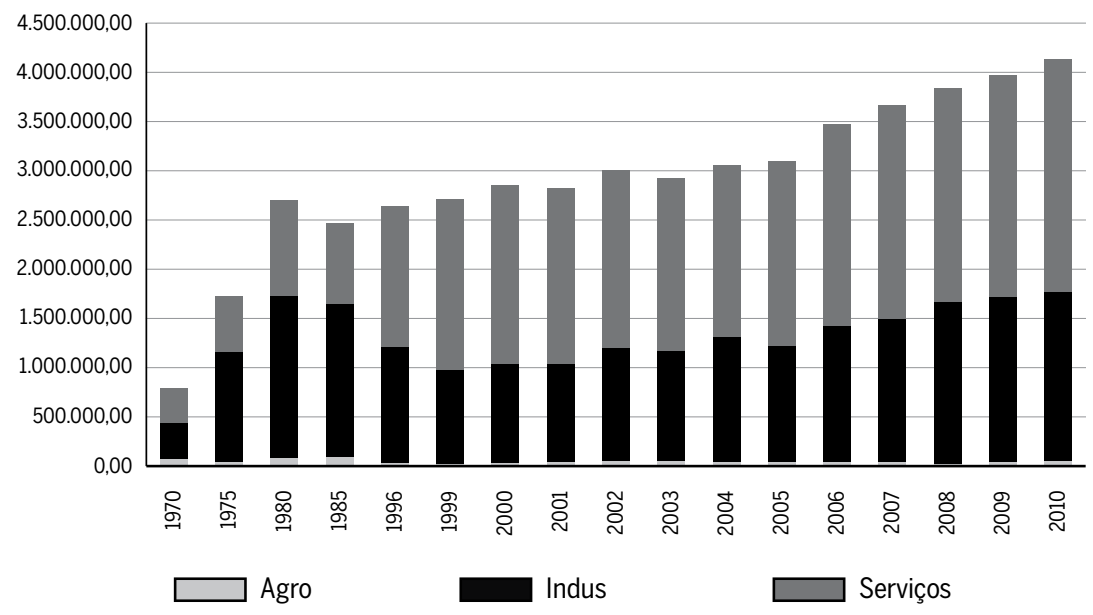

Fonte: IPEADATA. Elaboração própria.

As perspectivas favoráveis impulsionaram a montagem do Arranjo Produtivo Local do Álcool (APLA), em 2005, e do Parque Tecnológico (PTP), implantado pelo Decreto Estadual n 50.504 e inaugurado em 2012. Este recebe centros de desenvolvimento e laboratórios de empresas especializadas em pesquisa para a conversão de fontes de biomassa em combustíveis renováveis e visa à cooperação entre poder público, centros de pesquisas, universidades, além de dar suporte às atividades empresariais. $O$ empreendimento, em parceria com o governo estadual, teve custo total estimado em R \$ 80 milhões, cabendo à Prefeitura arcar com de 10\% desse montante.

Ressalte-se que o empresariamento urbano pautou a gestão piracicabana a partir da década de 2000 por meio de diversas parcerias entre poder público e iniciativa privada. A própria iniciativa da elaboração do planejamento 
estratégico ${ }^{11}$ partiu de articulação envolvendo representantes de empresas, universidades, técnicos e gestores públicos sob a liderança da unidade local da Caterpillar do Brasil: elaborado no bojo da "Agenda 21", estabeleceu a diversificação industrial como meta prioritária para o desenvolvimento local, visando principalmente à redução da dependência da indústria metalomecânica em relação ao setor sucroalcooleiro (Giuliani; Pizzinatto, 2015). O poder público fez sua parte: visando beneficiar-se da relocalização industrial, desapropriou área rural de 1,84 milhão de $\mathrm{m}^{2}$ cultivada com cana-de-açúcar - ao custo de $\mathrm{R} \$ 5,5$ milhões aos cofres municipais -, para a construção de um Centro Automotivo liderado pela empresa coreana Hyundai, o que representou um dispêndio total em torno de $\mathrm{R} \$ 47$ milhões. A fábrica começou a operar em 2012, apta a produzir 150 mil veículos/ ano e a elevar a participação do município no Imposto sobre Circulação de Mercadorias e Serviços (ICMS).

Importante decorrência do empresariamento urbano foi a intensificação da periferização da cidade e consequente produção de vazios urbanos grandes glebas desocupadas, em geral estocadas e dotadas de infraestrutura, localizadas nos interstícios da mancha urbanizada, à espera de valorização imobiliária. A despeito de o Plano Diretor ter definido como eixo estruturador o congelamento do perímetro urbano, este foi expandido em oito oportunidades entre 2004 e 2010, passando de 164,04 km² para 211,7 km², ampliando as áreas industriais: em 2006 a implantação do Distrito Industrial Noroeste para a instalação de uma joint-venture do setor sucroenergético, a Raízen, e em 2008 para a implantação do Centro Automotivo. Contradições flagrantes entre planejamento urbano municipal e as demandas econômicas de grupos privados (Goulart; Terci; Otero, 2013). O encarecimento do solo foi de $100 \%$, pois os novos distritos se localizam em antigas áreas rurais incorporadas ao perímetro urbano. ${ }^{12}$

11 O denominado planejamento estratégico tem sido a fórmula recomendada pelas agências internacionais como o Bird e o Habitat para a adoção das estratégias de gestão empresarial na administração urbana, entendendo que contemporaneamente as cidades enfrentam desafios semelhantes aos das empresas. Um dos entusiastas e difusores dessa concepção destaca: "the flexibility, globalization, and complexity of the new world economy require the development of strategic planning, able to introduce a coherent, adaptative methodology in the multiplicity of meanings and signals of the new structure of production and management" (Castells, 1992, p. 77).

12 A esse respeito, ver a matéria "Terras valorizaram 170\% no interior de São Paulo em três anos". Disponível em: <http://www.canalrural.com.br/noticias/agricultura/terras-valorizaram-170-interior-sao-paulo-tres-anos-25062, 13/01/2014>. Acesso em 13 jan. 2014. 


\section{Bauru}

Bauru apresentou crescimento do VA entre 1980 e 1996, ponto de inflexão para um declínio sistemático até 2004, com ligeira recuperação em 2002. A prevalência do setor serviços é característica histórica do município, mas o crescimento da indústria foi expressivo até 1996, quando apresentou sua maior participação $(34,65 \%$ do VA).

\section{Gráfico 3 Bauru - evolução total e setorial do Valor Adicionado (reais de 2000)}

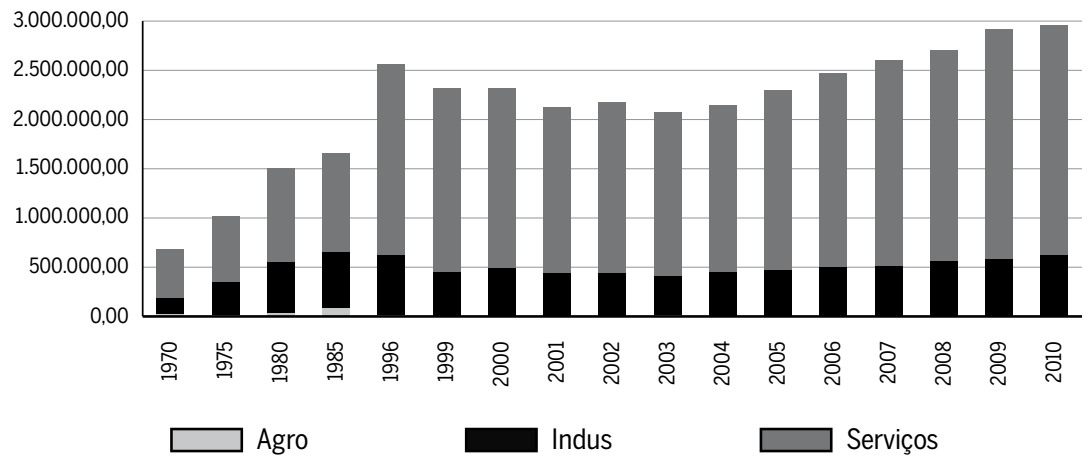

Fonte: IPEADATA. Elaboração própria.

Já em 1967, o primeiro Plano Diretor de Desenvolvimento municipal estabelecia que "Industrialização é a meta", prevendo a implantação de um Distrito Industrial e a atração de indústrias com a oferta de terrenos, isenção e restituição de tributos municipais, vias de acesso, água, esgoto e energia elétrica. Ademais, as potencialidades locais foram alardeadas tendo em vista atrair indústrias, destacando-se a disponibilidade do poder público de fornecer infraestrutura, classe trabalhadora "bem comportada" e facilidade de transportes devido à localização privilegiada (Losnak, 2004).

O perímetro urbano ampliou-se com a abertura de "loteamentos operários", pois se entendia que "vender lotes seria oferecer infraestrutura para uma virtual cidade industrial e operária" (Losnak, 2004, p. 135). O dinamismo industrial, contudo, ficou aquém, chegando à década de $2000 \mathrm{com}$ cerca de $20 \%$ de participação contra $80 \%$ dos Serviços. ${ }^{13}$

13 Estudo do Seade (2012) sobre a evolução do PIB na Região Administrativa de Bauru na década de 2000 é esclarecedor: considerando a região, o setor serviços manteve a prevalência no PIB regional, ainda que com leve queda entre 2000 e 2010 : de $68,3 \%$ para $66,3 \%$. Tal 
A cidade tem três distritos industriais e busca viabilizar um quarto na Rodovia SP-321, recém-duplicada em razão da instalação de um moderno aeroporto. A preocupação com o fraco desenvolvimento industrial mantém-se em pauta e denuncia o empresariamento na concepção da gestão urbana. Uma explicação para essa difícil alavancagem é a restrição ambiental à expansão das áreas industriais, especialmente no Distrito Industrial 2, localizado em área coincidente com "um dos maiores orgulhos ambientais do município - sua mata de cerrado". Em 2011, diretores do CIESP alertavam que indústrias interessadas em instalar-se ou expandir atividades no município estavam impedidas por esse entrave. ${ }^{14}$

A alternativa sugerida no Plano Diretor Participativo de 2008 não solucionou o problema e, adicionalmente, contribuiu para intensificar a especulação imobiliária. Trata-se da proposta de criação de minidistritos em áreas periféricas da cidade, com os objetivos de gerar empregos, ocupar os vazios urbanos e "propiciar à população de baixa renda um aumento de seus recursos obtidos pela diminuição dos gastos com transporte e ampliação das oportunidades de trabalho". A meta é criar sete áreas com lotes adequados a empresas de pequeno porte, com recursos provenientes de um fundo alimentado com recursos de leilões de terrenos. A partir do primeiro, a Prefeitura reuniria recursos para abrir as demais áreas e ampliar a infraestrutura das já existentes, incluindo os Distritos 1, 2 e 3.

A escassez de área contribui para encarecer o solo e estimular a atratividade de cidades vizinhas, o que recoloca em pauta a revisão da legislação ambiental, conforme indica o CIESP. A proposta dos minidistritos encontrou oposição justamente no segmento social que pretensamente buscava atender: os habitantes do Bairro Jardim Pagani, seu projeto piloto. Para a Associação do Bairro, "existem muitas alternativas para o local que são melhores para a comunidade do que uma intensificação da atividade industrial que contribuirá para que a já precária infraestrutura do bairro se deteriore". ${ }^{15}$

prevalência é determinada pelo peso econômico de Bauru, que representou, respectivamente, 36,9\% e 33,3\% do PIB regional entre 2000 e 2010, enquanto demais municípios expressivos - Lins, Lençóis Paulista e Jaú -, não atingiram os 10\% de participação. Os quatro municípios representaram 62,3\% do PIB regional em 2000 e 61,8\% em 2010 (Bessa, 2012).

14 A esse respeito, ver a matéria jornalística "Bauru tem fila de espera de espera de 30 indústrias". Jornal da Cidade, 15/06/2011. Disponível em: <http://www.jcnet.com.br/Economia/2011/06/bauru-tem-fila-de-espera-de-30-industrias.html>. Acesso em 09 mar. 2015.

15 A esse respeito, ver "De novo o mini-distrito industrial". Disponível em: $<$ http://novojardimpagani.blogspot.com.br/201103/de_novo_o_mini-distrito_industrial.html>. Acesso em 05 mar. 2015. 
A importância regional da cidade polariza o entorno e explica a pujança do setor Serviços, oportunizando empreendimentos especulativos em dois shoppings centers: o Villaggio Mall Center (ao lado de condomínio fechado de alta renda), e o Shopping Nações, instalado na área central. Idealizado por um grupo norte-americano (Carlyle), o Shopping Nações foi viabilizado por um consórcio reunindo três empreendedores (Vertico, GCD Malls e Marca) e a escolha por Bauru foi estratégica, confirmando o caráter especulativo dessas escolhas, que a identificaram como a única cidade "grande" do interior ainda sem um shopping regional. O impacto sobre o emprego foi expressivo e posicionou Bauru no $4^{\circ}$ lugar no ranking de empregabilidade na construção civil em 2011, atrás apenas de São Paulo, Campinas e Ribeirão Preto (Fiesp, 2014).

\section{Rio Claro}

Rio Claro apresentou crescimento importante do VA entre 1980 e 1996, impulsionado pela indústria, que, em 1985, representava o melhor desempenho $(60,11 \%)$. O município foi grande beneficiário do processo de interiorização dos anos 1970: tradicionalmente especializado na produção e reparação de material ferroviário e nas indústrias têxtil e cervejeira, diversificou essa produção ao receber cerca de 30 novos empreendimentos industriais entre grandes e médios (Pires; Sampaio, 2000).

\section{Gráfico 4 Rio Claro - evolução total e setorial do Valor Adicionado (reais de 2000)}

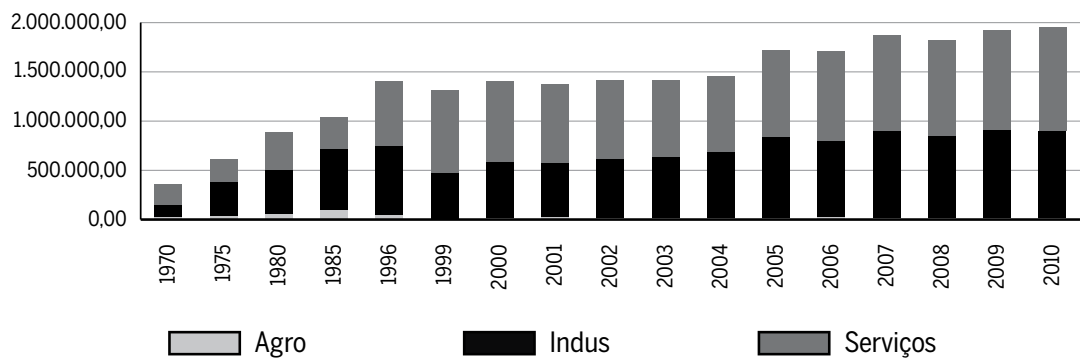

Fonte: IPEADATA. Elaboração própria.

O crescimento da economia local não se sustentou e a indústria declinou principalmente entre 1996-99, quando encolheu aproximadamente 34\%, 
baixando o VA e refletindo os efeitos da abertura econômica e da reestruturação industrial, as quais implicaram na perda de alguns de seus maiores estabelecimentos, como a cervejaria Skol-Caracu, a têxtil Cianê e a Gurgel veículos, além das Oficinas da FEPASA. Assim, "em 1992 a Região de Rio Claro apresentava uma participação de $0,456 \%$ no valor adicionado da indústria estadual, a menor desde 1988" (Pires; Sampaio, 2000, p. 57).

Após o ajuste, a indústria rioclarense recuperou o fôlego e elevou sistematicamente sua participação no VA da indústria do estado, chegando em 1996 a participar com 0,598\%. Pires e Sampaio (2000) confirmam o impacto da relocalização da atividade econômica: apesar da perda de algumas unidades tradicionais, recebeu novos e modernos empreendimentos de capital estrangeiro, alterando significativamente seu perfil industrial: destaque para a Whirlpool Latin America, líder no mercado de eletrodomésticos. ${ }^{16}$

Aqui também o poder público adotou o empresariamento urbano. Através do Programa de Desenvolvimento de Rio Claro (Proderc) - reformulado pela Lei $n^{\circ} 2.788$, de 06/12/1995, valendo-se de renúncia fiscal -, a Prefeitura estimulou a instalação e ampliação de empresas mediante compromisso com metas de empregabilidade e oferta de vários incentivos: isenção total ou parcial do IPTU; isenção do preço público referente à obtenção da Licença para construção de obras particulares; isenção de ISSON; isenção da Taxa de Alvará de utilização, bem como de todos os Impostos e Taxas para legalização da inscrição junto ao Cadastro Municipal; isenção total do ITBI para fins exclusivos de acomodações e instalações operacionais da empresa. A Prefeitura ainda pode fornecer equipamentos e mão de obra para serviços de terraplanagem aos participantes do programa. Segundo a imprensa oficial, entre 2009 e 2011, foram fechados 86 contratos no âmbito do Proderc. Na avaliação do prefeito municipal, Du Altimari, "esse conceito nos interessa muito, tem a ver com a modernidade que os tempos exigem, exprime uma nova relação que se estabelece entre o homem e o mundo"! $!^{17}$

16 A Whirlpool Latin America atua no Brasil com as marcas Brastemp, Consul e KitchenAid com fábricas em Joinville (SC), Manaus (AM) e Rio Claro (SP). As indústrias Owens Corning Fiberglass S/A, Tubos e Conexões Tigre S/A, Brascabos Componentes Elétricos, Multibrás S/A Eletrodomésticos, Uniroyal Química S/A, Nheel Quimica Ltda., Aldoro Indústria Pós e Pigmentos Metálicos Ltda: "algumas dessas indústrias fazem parte de cadeias produtivas e de complexos industriais territorializados, produzem para outras empresas, e atuam no comércio exterior" (Pires; Sampaio, 2000, p. 58).

17 A esse respeito, ver: "Proderc fecha 2011 com R\$ 268 milhões acumulados em três anos". Canal Rio Claro, 22/12/2011. Disponível em: <http://www.canalrioclaro.com.br/noti- 
Ainda no âmbito do Proderc, experimenta-se um novo conceito de ocupação no Distrito Industrial da cidade: trata-se de loteamento industrial empreendido pela Corporate Park, empresa que atua em vários municípios brasileiros, cuja oferta de infraestrutura no distrito industrial é terceirizada. ${ }^{18}$

\section{Finanças públicas municipais na conjuntura recente}

A análise que se segue aborda duas variáveis: a) a evolução das receitas dos municípios, sua capacidade de arrecadação e, em que medida, estas refletem a dinâmica econômica anteriormente analisada; b) as prioridades de destino do gasto e a capacidade de investimento do poder público. ${ }^{19}$ Para tanto, cumpre iniciar pela evolução do Índice de Participação dos Municípios (IPM) no ICMS do estado de São Paulo, pois esses dados contribuem na análise sobre o desempenho econômico ao longo do tempo.

Em Piracicaba houve queda na participação desde 1980, com o pior desempenho em 1995, o que pode ser explicado pela retração econômica do país, crise do Proálcool e reestruturação produtiva. O município recupera-se na sequência e, em 2011, supera ligeiramente o índice de 1980, seu melhor desempenho, impulsionado por grandes investimentos públicos e privados nos distritos industriais, parques produtivos e pelos setores automotivo e de máquinas e equipamentos. Não por acaso, esse impulso se deu no momento recente de maior dinamismo da economia nacional.

Bauru e Rio Claro, diversamente, ampliaram seu índice de participação desde 1980 (praticamente dobraram). Desde 1995, Bauru mantém praticamente o mesmo patamar, enquanto Rio Claro, embora tenha elevado sua participação a partir de 1980, sofreu o impacto da reestruturação produtiva da década de 1990, quando o índice caiu de 0,415 para 0,338, recuperando-se na sequência em virtude da modernização de seu parque industrial e dos incentivos fiscais provenientes do Proderc.

cia/6122/noticia/6123/noticia/6123/.html>. Acesso em 03/02/2015.

18 Disponível em: <http://www.corporateparkrioclaro.com.br/>. Acesso em 15 mar. 2015. 19 Utilizamos para essa análise a base de dados do SEADE, cujas fontes são o Ministério da Fazenda/Secretaria do Tesouro Nacional e Fundação SEADE/Pesquisa Municipal Unificada (PMU), pois se trata de base padronizada para todos os municípios, o que permite o estudo comparativo. 


\section{Gráfico 5 Piracicaba, Bauru e Rio Claro - índice de participação (\%) no ICMS do Estado de São Paulo}

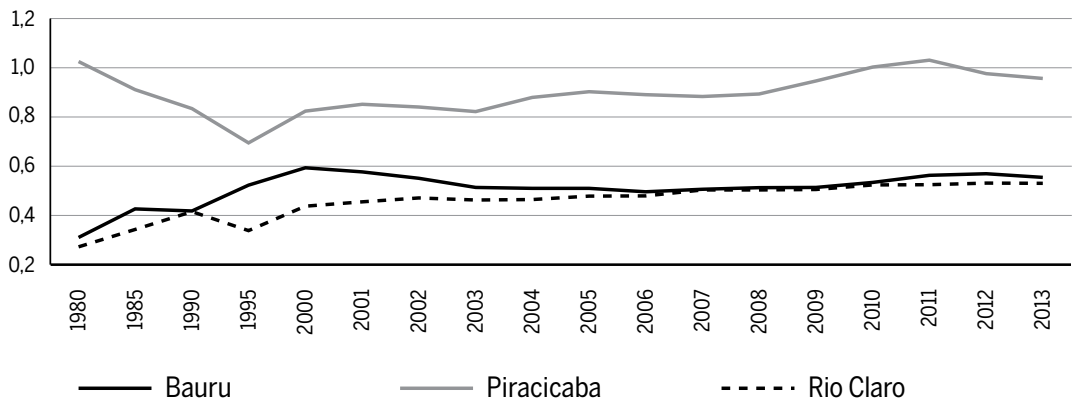

Fonte: SEADE. Elaboração própria.

Quanto ao comportamento das receitas dos três municípios na década de 2000, observa-se queda na arrecadação em 2002 e 2003, anos de baixo crescimento econômico. No período seguinte, entretanto, a recuperação foi sistemática para Piracicaba, com destaque para 2010, ano em que a receita tributária e a quota-parte do ICMS aumentam 14,31\% e 18,02\%, respectivamente, refletindo o cenário macroeconômico e os grandes investimentos realizados no período. Bauru teve comportamento semelhante nos anos 2002-2003, embora a queda na arrecadação já se fizesse sentir em 2001 (-2,71\%), recuperando-se em 2002. No ano seguinte, porém, a queda foi generalizada e a receita declinou em 8,74\% em relação a 2002.

No caso de Rio Claro, a evolução da receita municipal teve comportamento mais regular e ascendente até 2002 , declinando em seguida. ${ }^{20} 2002$ e 2003 foram seus anos de pior desempenho, sendo consecutiva a queda da receita tributária (-2,32\% em 2002 e -9,89\% em 2003) o fator de maior impacto, seguida da quota parte do ICMS, que, em 2002, manteve praticamente o mesmo número de 2001 e sofreu queda de -11,99\% em 2003. É possível inferir que a recuperação foi significativa no triênio 2004-06, quando os índices em relação a 2003 foram bastante expressivos (43,37\%); contudo, a partir de 2007 registra-se um comportamento bastante erráti-

20 Infelizmente a ausência de dados para alguns anos compromete a análise do desempenho. Causa estranheza os dados de 2007, pois, ainda que o comportamento geral da receita tenha se mantido (com um crescimento em $4,75 \%$ ), os únicos números disponíveis são os relativos às receitas tributárias; os dados de transferências governamentais não estão disponíveis e, ao que tudo indica, foram computados nas Transferências de convênios, que registrou comportamento absolutamente atípico, responsável por $65,62 \%$ da receita total. 
co, com queda na receita total de $-4,00 \%$ entre $2008-09$, elevando-se em $17,73 \%$ entre 2009-10 e declinando 4,00\% em 2011.

Gráfico 6 Piracicaba, Bauru e Rio Claro - evolução das receitas municipais entre 1980

\section{e 2011 (reais de 2013)}

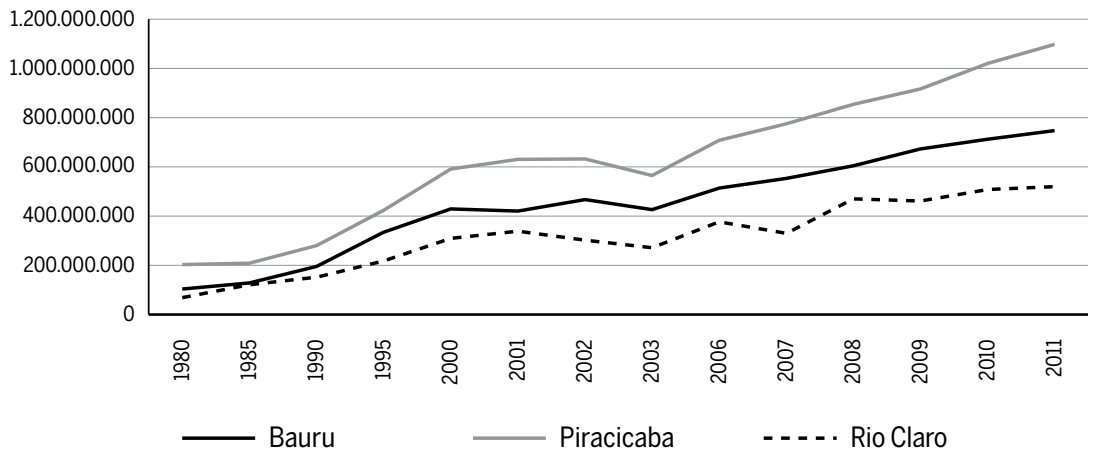

Fonte: SEADE. Elaboração própria.

\section{O gasto público}

Destacamos a seguir as prioridades de gastos dos governos municipais. Para tanto, privilegiamos os valores referentes à Gestão Ambiental, Saneamento, Habitação, Urbanismo e Investimentos, pois são as rubricas das despesas municipais diretamente ligadas aos gastos com o provimento de infraestrutura urbana (Bremaeker, 2008). Iniciamos pelas despesas municipais com investimentos, a única rubrica que permite análise desde 1980.

Piracicaba sofre forte retração dos investimentos entre 1980 e 1985, com leve recuperação em 1990, acompanhando o contexto de baixo crescimento da economia local no período. Em 1995, há um pico de investimento com a quase quadruplicação do montante de 1990 ( $\mathrm{R}$ 157,4 milhões), momento em que a economia local reagiu e experimentou expressiva elevação do VA. No início da década de 2000, entretanto, os investimentos declinaram, mantendo participação de $10 \%$ das despesas municipais correntes até 2006, quando novamente é alavancada, saltando do patamar de $17 \%$ naquele ano para $27 \%$ em 2011 . Tais investimentos estão relacionados a obras de grande envergadura na estrutura viária de Piracicaba, bem 
como às instalações dos distritos industriais, do Centro Automotivo e do Parque Tecnológico, evidências do empresariamento urbano. Salta aos olhos a enorme diferença de crescimento deste item da despesa municipal de Piracicaba em relação a Bauru e Rio Claro a partir de 2006.

\section{Gráfico 7 Piracicaba, Bauru e Rio Claro - evolução das receitas municipais com investi- mento entre 1980 e 2011}

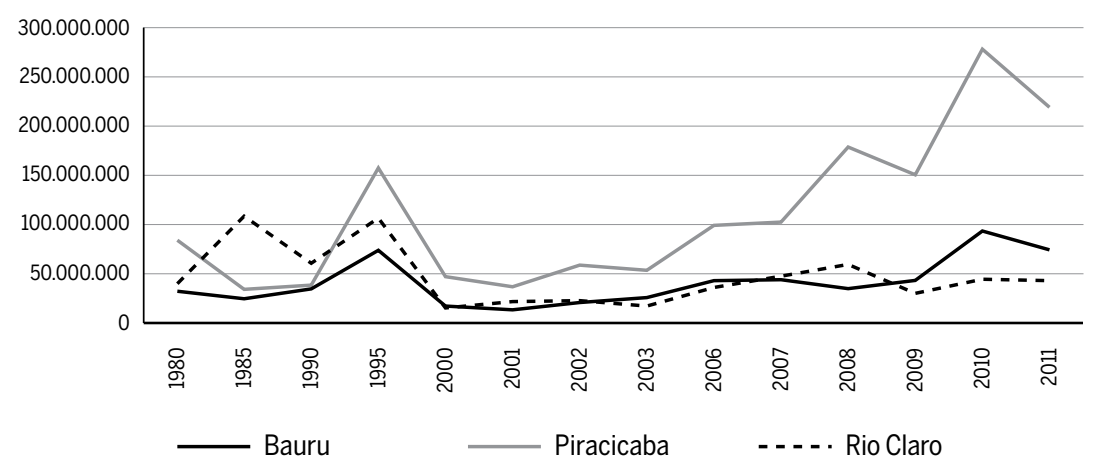

Fonte: SEADE. Elaboração própria.

Bauru registra queda nos investimentos públicos entre 1980 e 1985 (de $\mathrm{R} \$ 39,8$ milhões para $\mathrm{R}$ \$24,4 milhões), leve recuperação em 1990 e pico de elevação em 1995, quando atinge aproximadamente os mesmos valores de 2011 (cerca de $\mathrm{R} \$ 74$ milhões), coincidindo com os investimentos imobiliários do shopping center regional e de infraestrutura urbana. Em 1980, momento do esforço industrializante, chegou a 40\% das despesas municipais correntes, caindo a $18 \%$ em 1990, a $4 \% \mathrm{em}$ 2000, mantendo-se em torno de 10\% até o pico em 2010 (15\%), voltando aos $10 \%$ em 2011.

Em Rio Claro, a despesa com investimentos tem uma trajetória diferenciada, exceto no intervalo entre 1990 e 2000, quando, como os demais municípios analisados, após forte declínio entre 1985 e 1990, tem seu pico em 1995, o segundo maior valor de toda a série histórica ( $\mathrm{R} \$ 106,4$ milhões). O maior montante registrou-se em 1985 (R \$108,5 milhões), ano em que Piracicaba e Bauru registraram declínio. Aqueles picos de investimentos públicos ocorridos no início da série (em 1985 e 1995) coincidem com o período agudo da reestruturação produtiva do município. Nesses intervalos, a despesa com investimentos representou aproxima- 
damente $62 \%$ do total (1980), 86\% em 1985, $45 \%$ em 1990 e $59 \%$ em 1995, refletindo forte esforço de empresariamento urbano. Em 2000 desaba a apenas $5 \%$ das despesas correntes, permanecendo nesse patamar até 2006, quando se eleva a cerca de $10 \%$ de participação até o final do intervalo em 2011.

\section{Gráfico 8 Piracicaba, Bauru e Rio Claro - evolução do gasto com gestão urbana - $\%$ da despesa corrente (2003-2011)}

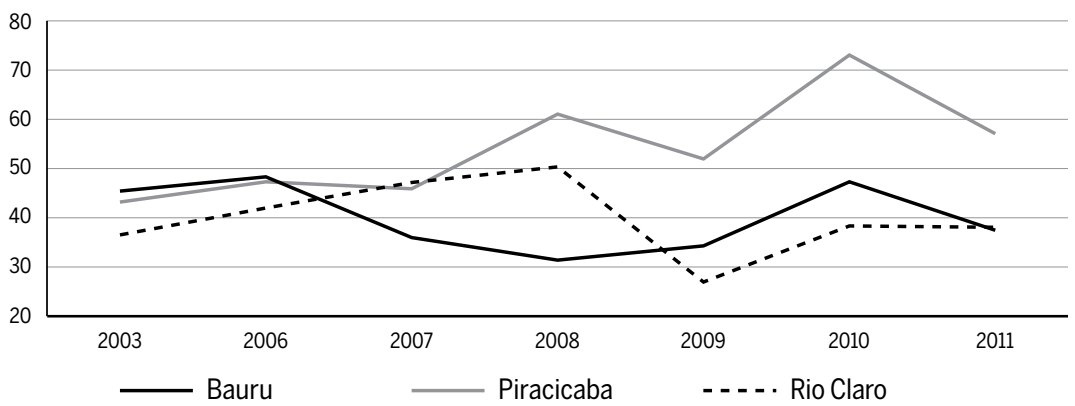

Fonte: SEADE. Elaboração própria.

Quanto à evolução das despesas com a gestão urbana (percentual das despesas correntes), observando-se o gráfico acima, tem-se uma situação diversa para os três municípios, principalmente a partir de meados da década (2006): enquanto Piracicaba descreve linha ascendente com esses gastos, atingindo mais de $70 \%$ das despesas correntes, Bauru apresenta sensível queda até 2008 (pior desempenho), oscila na sequência, nunca ultrapassando $50 \%$ das despesas correntes. Rio Claro, ao contrário, tem o pico de gastos com gestão urbana em 2008 (50\%), o ano da crise internacional, fechando o período abaixo dos $40 \%$ de participação.

A despeito de grande parte dos gastos públicos terem sido dirigidos à infraestrutura urbana, sobretudo à base das inversões recebidas, o passivo social das cidades brasileiras não é pequeno e se reproduziu nas cidades médias com o processo de interiorização da indústria. ${ }^{21}$

21 Embora "as cidades de porte médio tenham sido o território privilegiado do crescimento econômico e demográfico nas últimas décadas, configurando um quadro de 'espraiamento espacial da riqueza nacional' a partir dos anos 1970" não se pode ignorar que "essas cidades passaram a apresentar, ainda que em escalas distintas, grande parte dos problemas urbanos, físicos e sociais antes visíveis apenas nas grandes aglomerações urbanas" (Goulart; Terci; Otero, 2014, p. 21). 


\section{Considerações finais}

O estudo empírico dessas três cidades do interior paulista evidenciou forte sinergia entre poder público e setor privado na atenção aos interesses empresariais, confirmando a tendência ao empresariamento urbano, de modo a facilitar a instalação e ampliação de empreendimentos privados. Tal propensão foi favorecida pela ausência da ação articuladora do Estado brasileiro, permitindo que os níveis subnacionais de governo - municipal neste caso - assumissem maior protagonismo na perspectiva de mitigar os efeitos deletérios dos processos de liberalização e desindustrialização, submetendo-se assim às estratégias locacionais dos grupos econômicos.

Em síntese, o empresariamento urbano tem sido marcante na dinamização das economias locais, porém, as estratégias empregadas ao nível das políticas urbanas - periferização, renúncia fiscal, tensões ambientais - reproduzem velhos problemas e contribuem para o maior fator de segregação urbana: o encarecimento do solo e a especulação imobiliária. Essas políticas transcorreram no período de implantação do novo marco institucional da política urbana brasileira, com a revisão ou adoção de Planos Diretores orientados normativamente pelo Estatuto da Cidade. Os dados aqui analisados, todavia, permitem inferir que tais Planos não tiveram efetividade nos propósitos de oferecer terra urbanizada, conter a segregação socioespacial e assegurar a função social da propriedade e da cidade. Assim, o empresariamento adotado no plano econômico se revelou variável determinante na configuração do espaço urbano.

No caso de Piracicaba, após a severa retração provocada pela crise do Proálcool, o setor industrial se reestruturou fortalecendo o segmento de máquinas e equipamentos que consolidou sua liderança. Na perspectiva da diversificação, o governo local investiu recursos para atrair uma grande empresa do setor automotivo, haja vista os vultosos investimentos que entre 2008 e 2010 representaram 60\% das despesas correntes do município (Seade). O impacto dessa dinâmica sobre o mercado imobiliário e sobre o emprego foi expressivo: o emprego industrial voltou a crescer a taxas muito superiores às estaduais. Mas os impactos são igualmente dramáticos corroborando a expansão incontrolada do perímetro urbano e consequente intensificação da periferização.

Bauru consolidou-se como polo de serviços por várias razões: localização central que a consagrou como sede de importante polo urbano do 
oeste paulista e maior cidade de ligação entre seu entorno e a capital do estado (IBGE, 2008); cidade média dotada de moderna infraestrutura urbana reunindo unidades de importantes redes de comércio e serviços do país; polarização regional face aos efeitos positivos da dinâmica econômica do entorno composto por uma série de cidades de menor porte, cujo perfil produtivo é marcado pela indústria de transformação tradicional.

Rio Claro enfrentou profunda transformação em seu parque industrial com o processo de reestruturação produtiva, sofrendo a perda de estabelecimentos tradicionais. Como consequência, sua participação no VA da indústria paulista encolheu na década de 1990. Renasceu, entretanto, nos anos seguintes, tendo sido grande beneficiária da relocalização da atividade econômica no estado, quando recebeu novos empreendimentos com injeção de capital estrangeiro em segmentos modernos da indústria de eletrodomésticos, o que alterou significativamente seu perfil industrial. Isso foi possível graças à ação decisiva do poder público na atração e facilitação para novas inversões. Neste caso também valeu a velha fórmula da inserção subordinada aos padrões internacionais de competitividade empresarial: a associação com grupos capitalizados e consolidados nos mercados nacional e internacional, além da oferta de incentivos a grupos privados, destacadamente o Proderc.

Em um contexto de liberalização no qual o Estado perdeu protagonismo e meios para conduzir o desenvolvimento, a ação do poder público local foi marcante porque esta foi a fórmula identificada pelos gestores públicos tanto para a recuperação e dinamização da economia urbana e regional quanto para elevar suas receitas. Essa inflexão é inseparável de duas ordens de razões interconectadas: ao esvaziamento do Estado e de suas agências na formulação de políticas de desenvolvimento urbano e regional e, em razão desse vácuo e da assimetria federativa brasileira, caracterizada pela concentração de poder, as cidades e os governos locais assumiram o compromisso com a readequação de suas estruturas produtivas.

O problema central é que esse ativismo dos governos locais tem servido, em larga escala, aos interesses dos grupos privados, ensejando diferentes expressões de empresariamento sem que os irregularidades estruturais da urbanização fossem enfrentados satisfatoriamente. Pelo contrário, essa fórmula consagra a clivagem regional, não melhora substantivamente a infraestrutura urbana para as populações mais carentes (habitação social, mobilidade, saneamento, etc.) e reduz a cidade à condição de mercadoria, 
que, como tal, precisa ser vendida aos segmentos solventes, vale dizer, aos que podem comprá-la.

\section{Referências}

AMORIM F. ${ }^{\circ}$ O.; SERRA, R.V. Evolução e perspectivas do papel das cidades médias no planejamento urbano e regional. In: ANDRADE, T.A.; SERRA, R.V. Cidades Médias Brasileiras. Rio de Janeiro: IPEA, 2001.

BESSA, V. C. (Coord. tec.). PIB dos municípios paulistas 2000-2010. São Paulo: Fundação Seade. Dezembro/2012.

BRAGA, R. Cidades médias e aglomerações urbanas no estado de São Paulo: novas estratégias de gestão territorial. Anais do X Encontro de Geógrafos da América Latina. São Paulo, 20 a 25 de março de 2005.

BREMAEKER, F. E. As finanças municipais em 2007. Transparência Municipal. Estudo Técnico n. 2, 2008.

CANO, W. et al. Economia Paulista: dinâmica socioeconômica entre 1980 e 2005. Campinas: Alinea, 2007.

CANO, W. A desindustrialização no Brasil. Economia e Sociedade, Campinas, v. 21, Número Especial, p. 831-851, dez. 2012.

CARLOS, A. F. A.; VOLOCHKO, D.; ALVAREZ, I. P. (Orgs.). A cidade como negócio. São Paulo: Contexto, 2015.

CARNEIRO, R. Desenvolvimento em crise: a economia brasileira no último quarto do século XX. São Paulo: Ed. Unesp/IE Unicamp, 2002.

CASTELLS, M. The world has changed: can planning change? Landscape and Urban Planning, n. 22, p. 73-78. Elsevier Science Publishers B.V., Amsterdam. 1992.

CASTELLS, M.; BORJA, J. As cidades como atores políticos. Novos Estudos 45. Julho/1996.

CASTELLO BRANCO, M.L. Cidades médias no Brasil. In: SPÓSITO, E. S.; SPÓSITO, M. E. B.; SOBARZO, O. (Orgs.). Cidades médias: produção do espaço. São Paulo: Expressão Popular, 2006.

CASTRO, A. B. A reestruturação industrial brasileira no anos 90. Uma interpretação. Revista de Economia Politica, v.21, n. 3 (83), julho-setembro 2001.

DIEESE. Desindustrialização: conceito e a situação do Brasil. Nota Técnica n. 100, junho de 2011. Disponível em <www.dieese.org.br/notatecnica/notaTec100Desindustrializacao. pdf>. Acesso em 10 dez. 2012.

DINIZ, C. C. Desenvolvimento Poligonal no Brasil: nem desconcentração, nem contínua polarização. Revista Nova Economia, v. 31, n. 1, set. 1993.

FELDMAN, S.; LEME, M. C. S. Desenvolvimento econômico local: aliança e competição entre cidades. Espaço \& Debates - Revista de Estudos Regionais e Urbanos. Ano XVII, 2001.

FERNANDES, A. C. Da reestruturação corporativa à competição entre cidades: lições urbanas 
sobre os ajustes de interesses globais e locais no capitalismo contemporâneo. Espaço \& Debates - Revista de Estudos Regionais e Urbanos. Ano XVII, 2001.

FIESP. Ranking Municipal de Empregos. Disponível em <http://apps2.fiesp.com.br/regional/ (S(zj3yegbitb5ebnaq1hdtagiv))/DadosSocioEconomicos/RankingEmpregos.aspx>. Acesso em 28 out. 2014.

FIORI, J. L. Sobre o Consenso de Washington. Texto para Discussão n. 324. Rio de Janeiro: Instituto de Economia Industrial/UFRJ, 1995.

GIULIANI. A. C.; PIZZINATTO, N. K. (Orgs.). Planejamento Estratégico Municipal: a agenda 21 de Piracicaba. Segunda revisão 2016 a 2025. Piracicaba: Ed. Unimep, 2015. Disponível em: $<$ http://www.pira21.org.br/files/file_texto_52.pdf >.

GOULART, J. O.; TERCI, E. T.; OTERO, E. V. A dinâmica urbana de cidades médias no interior paulista sob o Estatuto da Cidade. Revista Brasileira de Estudos Urbanos e Regionais, v. $15 n^{\circ} 1,2013$.

HARVEY, D. Do gerenciamento ao empresariamento: a transformação da administração urbana no capitalismo tardio. Espaço \& Debates - Revista de Estudos Regionais e Urbanos. Ano XVI, n. 39, 48-64, 1996.

HARVEY, D. A produção capitalista do espaço. São Paulo: Annablume, 2005.

IBGE. Regiões de Influência das Cidades. Rio de Janeiro: IBGE, 2008.

LIPIETZ, A. Globalização, reestruturação produtiva e impacto intraurbano. Séminaire International Políticas Públicas para o manejo do solo urbano. 1996. Disponível em: <http://lipietz.net/ IMG/article_PDF/article_368.pdf>. Acesso em 16 jun. 2011.

LOSNAK, C. J. Polifonia Urbana: imagens e representações/Bauru-1950/1980. Bauru: Edusc, 2004.

OLIVEIRA, C. M. Entrepreneurialism: empresariamento ou empreendedorismo urbano duas traduções, dois significados. Anais do XVI ENANPUR: espaço, planejamento e insurgências. Belo Horizonte, 2015.

OREIRO, J. L.; FEIJÓ, C. A. Desindustrialização: conceituação, causas, efeitos e o caso brasileiro. Revista de Economia Política, v. 30, n. 2 (118), p. 219-232, abril-junho 2010.

PIRES, E. L. S.; SAMPAIO, S. Indústria e Exportação na Região de Rio Claro: problemas e desafios da competitividade industrial e do comércio exterior no limiar do século XXI. Geografia, Rio Claro, v. 25 (3), p. 45-71, dezembro de 2000.

SASSEN, S. As cidades na economia mundial. São Paulo: Studio Nobel, 1998.

SEADE. Informações dos Municípios Paulistas. Disponível em <http://produtos.seade.gov.br/ produtos/imp/index.php?page $=$ varinf\&var=944>. Acesso em 25 ago. 2014.

SCHUMPETER, J. A. Teoria do Desenvolvimento Econômico. São Paulo: Nova Cultural, 1997.

SOUZA, M. A. O II PND e a política urbana brasileira: uma contradição evidente. In: DEAK, C.; SCHIFFER, S. R. (Orgs.). O processo de urbanização do Brasil. São Paulo: EDUSP, 2004.

SUZIGAN, W.; FURTADO, J. Política Industrial e Desenvolvimento. Revista de Economia Política. v. 26, n. 2 (102), p. 163-185, abril-junho 2006.

TERCI, E. T. Industrialização e seus impactos na urbanização do interior paulista: uma análise comparada de Americana, Piracicaba e Santa Bárbara d'Oeste. História econômica \& História de Empresas. v. XII, n. 1, jan./jun. 2009. 
VAINER, C. Os liberais também fazem planejamento urbano? In: ARANTES, O.; VAINER, C.; MARICATO, E. A cidade do pensamento único: desmanchando consensos. Petrópolis: Vozes, 2000.

\section{Sobre o autor}

ElianaT.Terci-etterci@usp.br

Universidade de São Paulo, São Paulo, SP.

Jefferson O. Goulart-jgoulart@faac.unesp.br

Universidade Estadual Paulista, São Paulo, SP.

EstevamV.Otero - estevamotero@yahoo.com

Universidade Metodista de Piracicaba, Piracicaba, SP.

O presente artigo apresenta resultados parciais de pesquisa financiada pela Fundação de Amparo à Pesquisa do Estado de São Paulo (FAPESP), limitados à abordagem da dimensão econômica dos processos contemporâneos de desenvolvimento urbano das cidades selecionadas. Os autores agradecem os comentários valiosos do Professor Fernando Cezar de Macedo Mota do Instituto de Economia da UNICAMP que contribuíram sobremaneira para enriquecimento do texto.

\section{Sobre 0 artigo}

Recebido em 31 de março de 2015. Aprovado em 15 de dezembro de 2015. 